\title{
WACANA PENANDA KEKOHESIAN DAN KEKOHERENSIAN DALAM BERITA COVID-19 DI LIPUTAN6.COM
}

\author{
Zulfa Nur Maulida \\ e-mail: zulfanurmaulida7@gmail.com \\ Prodi Tadris Bahasa Indonesia \\ IAI Darussalam Blokagung Banyuwangi
}

\begin{abstract}
Abstrak
Penelitian ini bertujuan untuk menganalisis kohesi dan koherensi dalam berita covid-19 di liputan6.com edisi juni 2020. Tujuan penelitian ini adalah mendeskripsikan penanda kekohesian dan kekoherensian wacana berita di media online berrita Covid-19 edisi bulan Juni 2020. Penelitian ini bertujuan untuk mendeskripsikan wacana penanda kekohesian dan kekoherensian dalam berita Covid19 di Liputan6.com edisi bulan juni 2020. Mencari penanda kohesi dan koherensi apakah yang tertera dalam berita. Berdasarkan hasil analisis data ditemukan beberapa hal sebagai berikut. Pertama, penanda kekohesian gramatikal dengan menggunakan penanda referensi, substitusi, elipsis, dan konjungsi. Kedua, penanda kekohesian leksikal yang meliputi, antonimi, hiponimi, dan kolokasi. Ketiga, penanda kekoherensian ditemukan penanda kekoherensian "berpenanda". Penanda kekoherensian "berpenanda" meliputi koherensi aditif, koherensi kronologis, koehrensi kausalitas, dan koherensi kontras. Atas dasar hasil analisis data, dapat disimpulkan sebagai berikut. Pertama, penanda kekohesian pada berita covid-19 di Liputan6.com edisi bulan juni tahun 2020 pada umumnya menggunakan penanda kekohesian secara eksplisit. Kedua, penanda kekohesian gramatikal yang digunakan meliputi referensi, substitusi, elipsis, konjungsi, dan penanda kekohesian leksikal yang digunakan meliputi antonimi, hiponimi, kolokasi. Ketiga, penanda kekoherensian berita covid-19 edisi bulan juni 2020 pada umumnya menggunakan koherensi "berpenanda", seperti koherensi aditif, koherensi kronologis, koherensi kausalitas, dan koherensi kontras.
\end{abstract}

Kata Kunci: Wacana Penanda, Kohesi, Koherensi

\begin{abstract}
This study analyzes cohesion and coherence in covid-19 news in the June 2020 liputan6.com edition. The purpose of this study is to describe the markers of cohesion and coherence of news discourse in online media with the June 2020 edition of Covid-19. This study aims to describe the discourse markers of cohesion and coherence in the Covid-19 news on the June 2020 edition of Liputan6.com. Looking for markers of cohesion and coherence in the news. Based on the results of data analysis found several things as follows. First, markers of grammatical cohesiveness by using reference markers, substitution, ellipsis, and conjunctions. Second, markers of lexical cohesion which include antonymy, hyponymy, and collocation. Third, the markers of coherence are found as "signified" coherence. Markers of "tagged" coherence include additive coherence, chronological coherence, causality coherence, and contrast coherence. On the basis of the results of data analysis, it can be concluded as follows. First, the mark of cohesiveness in the covid-19 news on Liputan6.com in the June 2020 edition generally uses explicit cohesion markers. Second, the grammatical cohesive markers used include references, substitution, ellipsis, conjunctions, and lexical cohesive markers used include antonym, hyponym, and collocation. Third, the markers of the coherence of co-19 news in the June 2020 edition generally use "tagged" coherence, such as additive coherence, chronological coherence, causality coherence, and contrast coherence
\end{abstract}

Keywords: Discourse Markers, Cohesion, Coherence 


\section{A. Pendahuluan}

Alat paling penting dalam komunikasi adalah bahasa. Bahasa sangat diperlukan oleh manusia, sebab manusia sebagai mahluk siosial pada dasarnya selalu menginginkan adanya kontak dengan manusia lain. Bahasa juga mempunyai fungsi yang dapat membantu masyarakat berkomunikasi dan berinteraksi. Berkomunikasi dan berinteraksi sosial dalam masyarakat melalui bahasa dapat diwujudkan dengan wujud konkret yang berupa wacana. Wacana adalah salah satu bagian strata dari kebahasaan yang menduduki posisi yang paling tinggi. Wacana itu merupakan unsur kebahasaan yang relatif paling kompleks dan lengkap. Satuan pendukung wacana meliputi fonem, morfem, kata, frasa, klausa, kalimat, paragraf, hingga karangan yang utuh. Berdasarkan pernyataan itu, dapat dikatakan bahwa wacana itu merupakan satuan bahasa terlengkap, yang dalam tataran gramatikal merupakan satuan gramatikal yang paling tertinggi. Menurut (Rani dkk. dalam Nur Laksana Eko Rusminto 2015: 3) merumuskan bahwa wacana adalah satuan bahasa diatas tataran kalimat yang dipergunakan untuk berkomunikasi dalam konteks sosial. Menurut (Tarigan dalam Nur Laksana Eko Rusminto 2015: 3) wacana adalah suatu bahasa terlengkap dan tertinggi atau terbesar diatas kalimat atau klausa dengan kohesi dan koherensi yang tinggi dan berkesinambungan, yang mampu mempunyai awal dan akhir yang nyata. Dalam wacana, penanda kohesi dan koherensi juga berpengaruh terhadap suatu kejelasan hubungan antara bentuk bahasa yang satu dengan bahasa yang lainnya. Suatu wacana tidak dapat dipisahkan dari unsur kohesi dan koherensi yang muncul sebagai alat untuk menciptakan suatu kalimat yang selaras, utuh dan juga menjadi kepaduan yang lebih mudah untuk dipahami.

Wacana sebagai dasar pemahaman teks sangat diperlukan oleh masyarakat untuk memahami informasi yang dimuat dalam Liputan6.com. Wacana yang baik adalah wacana yang harus memperhatikan antar hubungan kalimatnya. Hal ini harus selalu diperhatikan untuk memelihara keterkaitan dan keruntutan antarkalimat. Salah satu aspek yang dimaksud, antara lain adalah aspek kohesi dan koherensi. Pengertian kohesi sendiri adalah hubungan antar bagian dalam teks yang ditandai dengan penggunaan unsur bahasa. Konsep kohesi pada dasarnya mengacu pada hubungan bentuk artinya unsur-unsur wacana (kata atau kalimat) yang digunakan untuk menyusun suatu wacana memiliki keterkaitan secara padu dan utuh (mulyana, 2005:26). Kohesi dibagi menjadi dua jenis yaitu kohesi leksikal dan kohesi gramatikal. Dari segi bentuknya atau struktur lahirnya wacana disebut dengan aspek gramatikal wacana yang meliputi pengacuan (reference), penyulihan (substitution), pelepasan (ellipsisi), dan perangkaian (conjungtion), sedangkan kohesi leksikal yang dianalisis dari segi makna atau struktur batin wacana yang dapat dibedakan menjadi enam bagian yaitu pengulangan (repitisi), padan kata (sinonim), sanding kata (kolokasi), hubungan atas bawah (hiponim), meronimi (hubungan 
bagian-seluruh), dan ekuivalensi (hubungan kesepadanan). Penanda kohesi muncul sebagai alat untuk menciptakan suatu kesamaan dan kepaduan informasi yang berimplikasi pada pemahaman wacana seperti yang ada dalam novel atau bacaan. Sedangkan koherensi adalah keterkaitan antara bagian yang satu dengan bagian yang lainnya. Sehingga kalimat tersebut memiliki suatu kesatuan makna yang dapat dibilang utuh (Brown dan Yule dalam Mulyana, 2005: 30). Kohesi dan koherensi merupakan salah satu syarat utama kewacanaan atau tekstualitas, keduanya merupakan salah satu konsep kepaduan. Jadi Pengertian kohesi adalah keterpaduan bentuk, sedangkan koherensi adalah kepaduan makna. Teks atau wacana yang kohesif berarti setiap unsur lahirnya terpadu secara internal dalam satuan teks lahir.

Sedangkan koherensi sendiri adalah kepaduan makna yang terdapat dalam wacana. Keterpaduan dalam sebuah paragraf akan dapat terpenuhi apabila kalimat-kalimat yang menyusun paragraf itu sendiri terjadi secara logis dan gramatikal dan berkaitan satu sama lain dan untuk mendukung gagasan utama. Menurut Rani, dkk. (2006: 134) terciptanya koherensi suatu wacana tidak hanya ditunjukan dengan adanya piranti kohesi, melainkan masih banyak faktor-faktor lain yang dapat mendukung terciptanya wacana yang koheren, misalnya latar belakang pengetahuan pemakai bahasa dalam bidang permasalahan, pengetahuan dalam latar belakang sosial budaya, kemampuan membaca tentang hal-hal yang tersirat dan sebagainya.

Penelitian ini mengkaji wacana pada Liputan6.com berupa berita penyebaran COVID-19 yang merupakan wacana yang berisi sebuah berita tentang penyebaran sebuah virus dansebuah kejadian yang aktual. Penelitian terhadap wacana berita COVID-19 pada Liputan6.com dilakukan dengan menggunakan kajian secara linguistik, yaitu analisis wacana. Analisis wacana berita COVID-19 pada Liputan6.com ini menitikberatkan pada mekanisme kohesi tekstual untuk mengungkapkan urutan kalimat yang dapat membentuk sebuah wacana menjadi koheren.

\section{B. Metode Penelitian}

Dalam sebuah penelitian pastinya peneliti membutuhkan dengan adanya metode yang akan dipakai dalam meneliti objek penelitiannya, maka dari itu metode sangat berperan dalam penelitian.Metode ini bersifat dinamis, karena merupakan salah satu faktor penyebab munculnya pelbagai persoalan yang dapat mendorong manusia untuk mancari sebuah jawaban dari permasalahan-permasalahan yang muncul dari sebuah objek. Dengan demikian, penelitian ini merupakan wujud dari ikhtiar seseorang yang dilakukan dalam upaya untuk memecahkansuatu masalah yang sedang dihadapi, namun tidak semua kegiatan yang dilakukan untuk memecahkan sebuah permasalahan itu dapat disebut penelitian. Tapi hal ini sangat bergantung pada jenis 
masalah dan serta prosedur yang digunakan oleh peneliti. Sugiyono (2016: 6) mengemukakan dalam bukunya bahwa metode penelitian ini merupakan cara yang bersifat ilmiah untuk dapat menemukan, mengembangkan serta membuktikan penelitiannya melalui data yang valid serta dengan berisikan pengetahuan sehingga dapat dimanfaatkan untuk memahami, memecahkan serta mengantisipasi masalah dalam bidangnya.

Dalam penelitian ini, peneliti menggunakan metode kualitatif. Metode kualitatif ini merupakan penelitian yang dimaksud untuk memahami suatu gejala fenomena tentang apa yang terjadi atau yang dialami oleh subjek penelitian misalnya perilaku, motivasi, persepsi, tidakan, dan lain-lain secara holistik serta dengan cara mendeskripsikan dalam bentuk susunan kata dan bahasa yang lebih mendetai pada suatu konteks khusus yang bersifat alamiah serta dengan memanfaatkan pelbagai metode alamiah guna mencapai sebuah hasil penelitian tersebut (Moleong, 2006: 6). Dalam penelitian ini, peneliti menggunakan metode deskriptif kualitatif yang bertujuan agar dapat mendeskripsikan secara rinci tentang diksi dan gaya bahasa yang terdapat pada album perdana Andmesh Kamaleng.

Dalam metode kualitatif ini, digunakan untuk mendapatkan data-data yang mendalam, serta yang mengandung makna. Penelitian kualitatif ini instrumennya adalah seorang peneliti tersebut atau yang disebut dengan human instrumen.Penelitian kualitatif ini digunakan untuk mengungkapkan suatu keadaan maupun sutu objek yang dalam konteksnya itu membahas atau mencari makna yang terkandung, atau pemahaman yang mendalam tentang suatu masalah yang tengah dihadapi yang nampak dalam bentuk data kualitatif, baik berupa dokumen, teks, kata, bahkan bentuk visual (gambar) (Yusuf, 2017: 43). penelitian kualitatif ini disajikan secara naratif, penelitian kualitatif ini merupakan fokus perhatian dengan beragam metode yang mencakup pendekatan interpretif dan naturalistik terhadap subjek kajian-kajiannya ( Norman K. Densiz dan Yvonna S. Lincoln, 2009: 2). Menurut Sugiyono ( 2017: 9) metode kualitatif deskriptif adalah metode yang dilakukan untuk mengetahui permasalahan tanpa membandingkan maupun menghubungkan dengan masalah yang ada dengan gambaran campur tangan dari peneliti tersebut terhadap suatu fenomena atau kejadian-kejadian. Menurut Jane Richie (dalam Sukmah Khofifah, 2019: 85) penelitian kualitatif adalah upaya untuk menyajikan dunia sosial, dan perspektif, dari segi konsep, perilaku serta persoalan tentang manusia yang telah diteliti. Penelitian ini diarahkan untuk memperoleh deskripsi yang objektif dan akurat aspek-aspek yang membangun kohesi dan koherensi pada berita COVID-19 di Liputan6.com edisi bulan Juni 2020. Adapun fakta-fakta yang akan dideskripsikan adalah aspek-aspek (kohesi dan koherensi) yang menjadi sarana keutuhan dan keterpaduan wacana pada berita COVID-19 di Liputan6.com edisi bulan Juni 2020, seperti kalimat, paragraf. 
Objek penelitian ini merupakan tujuan atau sasaran untuk mendapatkan dengan kegunaan tertentu yang bersifat objektif dan valid mengenai suatu hal (Sugiono, 2016: 144). Penelitian ini bukanlah penelitian lapangan yang analisis bersifat statis, melainkan sebuah analisis yang sangat dinamis serta dapat terus dikembangkan. Penelitian ini merupakan penelitian sebuah berita melalui analisis dokumen yang berupa studi pustaka. Maka dari itu, tidak diperlukan adanya waktu dan tempat yang khusus, karena bersifat kualitatif. Terpaut dengan analisis dokumen, tempat penelitian ini dapat dilakukan dimana saja dengan waktu kapan saja, bergantung pada pencarian sumber analisis data dan memperoleh objek penelitian. Penelitian kualitatif ini menggunakan objek penelitian yang diperoleh data penelitian berupa naskah (teks), yakni berita COVID-19 Liputan6.com edisi bulan Juni 2020

Sugiono (2015) mengemukakan bahwa, informan penelitian merupakan subjek yang dapat memahami seluruh informasi objek penelitian tersebut, baik pelaku maupun orang lain. Sedangkan menurut Moleong (2005: 90) informan merupakan orang yang mempunyai pengetahuan mengenai latar belakang penelitian serta bersedia untuk memberikan informasi menyangkut objek yang diteliti. Teknik pemilihan informan ini adalah teknik purposive atau disengaja. Teknik tersebut bersifat tidak acak, maka dari itu subjek penelitian itu dipilih berdasarkan pertimbangan peneliti. Untuk informan dalam penelitian ini adalah peneliti sendiri yang mengetahui sumber informasi mengenai objek.

Sumber data penelitian ini adalah berita-berita COVID-19 di Liputan6.com edisi bulan Juni 2020. Berita tersebut terbit pada bulan Juni tahun 2020. Adapun yang menjadi data penelitian ini adalah kalimat-kalimat dalam berita COVID-19 di Liputan6.com yang diduga mengandung unsur kekohesian dan kekoherensian. Peneliti memilih berita sebagai sumber data penelitian karena sudah ditemukan banyak penilitian serupa lainnya yang menganalisis penanda kekohesian dan kekoherensian pada tajuk rencana dan kolom dalam berita dalam surat kabar, sehingga peneliti tertarik untuk menganalisis artikel dalam berita COVID-19 di Liputan6.com edisi juni 2020.

https://www.liputan6.com/health/read/4268028/update-1-juni-2020-pasien-positif-covid19-bertambah-467-total-26940-orang https://www.liputan6.com/health/read/4268872/update-2-juni-2020-kasus-positif-covid19-27549-sembuh-7935-meninggal-1663

https://surabaya.liputan6.com/read/4270176/update-corona-covid-19-di-jatim-3-juni-2020pasien-sembuh-bertambah-292-orang https://www.liputan6.com/bisnis/read/4265826/pns-mulai-jalani-new-normal-5-juni-2020 
- Analisis data merupakan upaya yang dilakukan untuk mengklasifikasi, mengelompokkan data (Mahsun, 2007: 253). Dalam rangka pengklasifikasian dan pengelompokkan data tentu harus didasarkan pada apa yang menjadi tujuan penelitian. Tujuan penelitian itu sendiri adalah memecahkan yang menjadi fokus penelitian.

Penelitian ini merupakan penelitian deskriptif kualitatif. Peneliti menganalisis penanda kohesi dan koherensi antarkalimat pada artikel dalam berita COVID-19 di Liputan6.com edisi bulan Juni 2020, kemudian mendeskripsikannya secara sistematis. Teknik yang digunakan adalah analisis wacana karena kalimat-kalimat tidak dianalisis dalam satu paragraf namun dianalisis berdasarkan hubungan antarkalimat yang satu dengan kalimat yang lain di dalam wacana. Dalam penelitian ini menggunakan konteks yang bersifat intralinguistik atau dengan kata lain pertalian makna antarkalimat diungkap berdasarkan hubungan antar kalimat yang satu sengan kalimat yang lain di dalam teks.

Untuk mengetahui penanda kohesi dan koherensi antar kalimat pada berita COVID-19 di Liputan6.com edisi bulan Juni 2020 digunakan metode agih, yaitu metode yang alat penentunya merupakan bagian dari bahasa yang bersangkutan, yaitu berupa wacana tulis yang dibentuk dengan menggunakan bahasa. Teknik dasar yang digunakan adalah teknik bagi unsur langsung yaitu cara yang digunakan pada awal kerja analisis dengan membagi satuan lingual data menjadi beberapa bagian atau unsur, dan unsur-unsur yang bersangkutan dipandang sebagai bagian yang langsung membentuk satuan lingual yang dimaksud (Sudaryanto 1988:31). Jadi wacana yang dianalisis berupa penggalan-penggalan wacana yang terdiri atas klausa dan kalimat. Hal itu dilakukan untuk memudahkan langkah-langkah penganalisisan lebih lanjut (Sudaryanto, 1988: $31)$.

\section{Hasil Dan Pembahasan}

Kohesi merupakan aspek penting dalam analisis sebuah wacana atau karangan. Kohesi dapat dibagi menjadi dua yaitu kohesi gramatikal (gramatical cohesion) dan kohesi leksikal (lexsical cohesion). Kohesi gramatikal mengacu pada hubungan antarunsur dalam wacana yang direalisasikan melalui tata bahasa, sedangkan kohesi leksikal mengacu pada hubungan antarunsur dalam wacana yang direalisasikan secara semantik.

\section{a. Kohesi Gramatikal.}

Konsep kohesi gramatikal mengacu pada hubungan antarunsur dalam wacana yang direalisasikan melalui tata bahasa. Kohesi gramatikal itu muncul jika terdapat unsure lain 
yang dapat ditautkan dengannya. Aspek gramatikal wacana meliputi: pengacuan (reference), penggantian (substitution), pelesapan (ellipsis), dan perangkaian (conjunction).

\section{Pengacuan (Reference)}

Pengacuan (Reference) merupakan bagian kohesi gramatikal yang berkaitan dengan penggunaan kata atau kelompok kata atau satuan gramatikal lainnya M.Ramlam dalam Mulyana (2005: 27). Referensi dapat dibagi menjadi tiga, yaitu referensi persona, referensi demonstratif, dan referensi komparatif.

\section{Referensi Persona}

Referensi persona adalah salah satu jenis kohesi gramatikal yang berupa kata ganti orang yang mengacu pada satuan lingual lain (atau suatu acuan) yang mendahului atau mengikutinya. Referensi persona dapat dibedakan menjadi referensi persona I (tunggal dan jamak), referensi persona II (tunggal dan jamak), dan referensi persona III (tunggal dan jamak)

Pemakaian referensi persona, dapat dilihat pada data berikut.

a) Ia menambahkan, kasus Covid-19 di Pasar Raya merupakan kasus transmisi lokal.

b) Menurut dia sejak pemberlakuan pembatasan sosial berskala besar di Sumatera Barat, tidak ada lagi kasus Covid-19 impor di Sumatera Barat. ( Liputan6.com 8 juni 2020)

Pada contoh (1) kata Ia mengacu pada narasumber yang member keterangan dalam berita tersebut. Dan pada contoh (2) kata dia juga mengacu pada orang tunggal III yaitu narasumber yang memberikan informasi dalam berita tersebut.

\section{Penggantian (Subtitution)}

Penggantian (substitution) adalah salah satu jenis kohesi gramatikal yang berupa penggantian satuan lingual tertentu (yang telah disebut) dengan satuan lingual lain dalam wacana untuk memperoleh unsur pembeda.

Pemakaian penggantian (Subtitution ), dapat dilihat pada data tersebut.

1) Dalam acara Halalbihalal dan Webinar dengan tema "Siapkah Masyarakat Sumbar Menjalani New Normal" yang diselenggarakan oleh Ikatan Alumni Fakultas Ilmu Sosial dan Ilmu Politik Universitas Andalas itu, Irwan mengatakan, kata kunci dalam penerapan 
tatanan normal baru adalah disiplin menjalankan protokol kesehatan terkait pencegahan Covid-19.

2) "Apa saja? Pakai masker, saat bertemu orang berjarak secara fisik, cuci tangan, mengurangi pertemuan langsung," ujar dia.( Liputan6.com 8 juni 2020)

3) Kalimat (1) pakai masker saat bertemu otang banyak, cuci tangan, mengurangi pertemuan langsung pada kalimat (2) merubah bentuk yang menggantikan unsur lain yang telah di sebutkan sebelumnya, yaitu protokol kesehatan. Pola penggantian ini menyebabkan kedua kalimat tersebut kohesif.

\section{Pelepasan ( Elipsis )}

Elipsis kata adalah salah satu jenis kohesi gramatikal yang berupa penghilangan atau pelesapan satuan lingual berupa kata yang telah disebutkan sebelumnya. Pelepasan (ellipsis), dapat dilihat pada data tersebut.

"Saya berharap semoga pandemi virus corona ini segera berahir, semoga demikian". Ucap Gubernur DKI Jakarta.

Demikian pada kalimat tersebut merupakan subtitusi dari kalimat klausan semoga pandemi virus corona ini segera berahir; sedangkan semoga adalah ellipsis untuk semoga pandemi virus corona ini segera berahir. Jadi, baik subtitusi ataupun ellipsis dapat terjadi pada seluruh kalimat. Subtitusi dan ellipsis seperti ini di sebut klausa subtitusi dan klausa ellipsis Lubis dalam Nur Laksana Eko Suminto (2015: 30).

5. Kata Sambung ( Konjungsi)

Konjungsi adalah kata yang digunakan untuk menggabungkan kata dengan kata, frasa dengan frasa, klausa dengan klausa, kalimat dengan kalimat atau paragraf dengan paragraf. Contoh konjungsi yang menggabungkan kalimat dengan kalimat atau klausa dengan klausa adalah agar, dan, untuk, ketika, sejak, sebelum, sedangkan, tetapi, karena, sebab, dengan, jika, sehingga, dan bahwa. Sementara itu, contoh konjungsi yang menghubungkan paragraf dengan paragraf adalah sementara itu, dalam pada itu, dan adapun.

Berdasarkan perilaku sintaksisnya dalam kalimat Alwi,dkk dalam Nurlaksana Eko Suminto (2015: 31) membagi konjungsi menjadi,(1) konjungsi koordinatif, (2) konjungsi 
korelatif, (3) konjungsi subordinatif, dan (4) konjungsi antar kalimat (berfungsi pada tataran wacana).

a. Konjungsi koordinatif

Konjungsi koordinatif berfungsi menghubungan dua klausa yang setara atau penghubung antarkata yang membentuk frase.

Konjungsi koordinatif dapat dilihat dari data tersebut.

1) Sumatera Barat termasuk daerah yang pertama menerapkan tatanan normal baru.

2) Kita harus berusaha agar terhindar dari virus corona.

Dalam data (1) kata yang menghubungkan dua klausa atau lebih, dan (2) agar menghubungakn dua kalusa yaitu kita harus berusaha agar terhindar dari virus corona.

b. Konjungsi korelatif

Konjungsi korelatif adalah konjungsi yang menghubungkan dua kata, frase atau klausa yang memiliki status sintaksis yang sama. Konjungsi ini terdiri atas dua bagian yang dipisahkan oleh satu kata, frase atau klausa yang dihubungkan.

Konjungsi korelatif dapat dilihat dari data tersebut.

"Dari seluruh kabupaten dan kota di Sumbar sudah berkurang, kecuali di Padang itu pun hanya di Pasar Raya," kata dia.

c. Konjungsi subordinatif

Konjungsi subordinatif adalah konjungsi yang menghubungkan dua klausa atau lebih, dan klausa tersebut tidak memiliki status sintaksis dan semantisnya.

Konjungsi subordinatif dapat dilihat dari data tersebut.

1) Gubernur DKI Jakarta Anies Baswedan menyampaikan, perpanjangan Pembatasan Sosial Berskala Besar (PSBB) Provinsi DKI Jakarta hingga 4 Juni 2020 menjadi fase penentu masa transisi menuju kenormalan baru atau new normal. .( Liputan6.com 4 juni 2020)

2) "Perpanjangan ini adalah masa menentukan. Mengapa? Karena apabila di harihari ini, penularan di Jakarta menurun, angka kasus baru menurun,” jelas Anies di Graha BNPB, Jakarta.

Pada contoh (3) atau menghubungkan kata dengan kata, sedangkan pada (4) karena menghubungan klausa dengan klausa.

d. Konjungsi antar kalimat 
Konjungsi antar kalimat adalah konjungsi yang menghubungkan satu kalimat dengan kalimat lainnya. Oleh karena itu, konjungsi ini selalu memulai suatu kalimat baru dan tentu saja huruf pertamanya menggunakan huruf kapital. Contoh konjungsi antar kalimat adalah Biarpun demikian/begitu, Sekalipun demikian/ begitu, Walaupun demikian begitu, Meskipun demikian/ begitu, Sungguhpun demikian/ begitu, Kemudian, Sesudah itu, Selanjutnya, Sebaiknya, Namun, Akan tetapi, Dengan demikian, Oleh karena itu, Bahkan, Tambahan pula.

Konjungsi antar kalimat dapat dilihat dari data tersebut.

1) Sonia menjelaskan jika hidup mereka sangat tertib dan disiplin selalu membersihkan diri dan taat melakoni protokol kesehatan sesuai ketentuan WHO. "Untuk itu, kita harus bersatu dan bersama-sama melawan Coronavirus dengan selalu menggunakan disinfektan spray LAVme,"tandas Sonia.

2) Yang membedakan LAVme dengan produk yang lain, kata Sonia adalah LavMe berkualitas tinggi dengan bahan baku food grade dan aman untuk disemprot di ruang bayi, anak, dan keluarga.

Pada contoh (1) kata untuk itu adalah konjungsi yang menghubungkan satu kalimat dengan kalimat lainnya. Oleh karena itu, konjungsi ini selalu memulai suatu kalimat baru dan tentu saja huruf pertamanya menggunakan huruf kapital. Begitupun juga kalimat (2) kata yang menhubungkan kalimat membedakan LAVme dengan produk yang lain, kata Sonia adalah LavMe berkualitas tinggi dengan bahan baku food grade dan aman untuk disemprot di ruang bayi, anak, dan keluarga.

\section{b. Kohesi Leksikal}

Kohesi leksikal atau perpaduan leksikal adalah hubungan leksikal antara bagian-bagian wacana untuk mendapatkan keserasian struktur secara kohesif. Unsur kohesif leksikal terdiri atas sinonim (persamaan), antonim (lawan kata), hiponim (hubungan bagian atau isi), repetisi (pengulangan), kolokasi (sanding kata), dan ekuivalensi. Tujuan digunakannya aspek-aspek leksikal itu diantara ialah untuk mendapatkan efek intensitas makna bahasa, kejelasan informasi, dan keindahan bahasa lainnya.

1. Antonim ( lawan kata )

Antonim atau lawan kata adalah mengemukakan hubungan antar kalimat dengan cara mententangkan kata-kata. Antonim atau lawan kata dapat dilihat dari data berikut:

1) Sebelumnya, Presiden Joko Widodo atau Jokowi meminta para kepala daerah menerapkan tatanan kehidupan baru atau new normal melalui tahapan yang ketat. Dia 
mengingatkan anggota dewan atau jajarannya agar betul-betul berhati-hati sebelum menetapkan new normal di suatu daerah.

2) Gubernur DKI Jakarta menerapkan kehidupan baru di era new normal. Beliau menghimbau agar semua masyarakat tetap memenuhi protokol kesehatan di era new normal tersebut.

3) Presiden Jokowi Dodo adalah antonin dari anggota dewan dan (2) Gubernur adalah antonim dari masyarakat.

2. Hiponim ( hubungan kata atau isi )

Hiponimi ( hubungan kata atau isi ) adalah nama atau kata yang termasuk di bawah atau di cakupi nama atau kata lain. Misalnya melati, mawar, anggrek merupakan hiponimi dari kata bunga. Kata bunga adalah hipernim. Hipernim adalah nama yang membawahi atau mencangkupi nama-nama lainnya Lyon dalam Nurlaksana Eko Suminto (2015: 34). Hiponimi ( hubungan kata atau isi ) dapat dilihat dari data berikut.

1) Dalam acara Halalbihalal dan Webinar dengan tema "Siapkah Masyarakat Sumbar Menjalani New Normal" yang diselenggarakan oleh Ikatan Alumni Fakultas Ilmu Sosial dan Ilmu Politik Universitas Andalas itu, Irwan mengatakan, kata kunci dalam penerapan tatanan normal baru adalah disiplin menjalankan protokol kesehatan terkait pencegahan Covid-19.

2) "Apa saja? Pakai masker, saat bertemu orang berjarak secara fisik, cuci tangan, mengurangi pertemuan langsung," ujar dia.

Kata protokol kesehatan pada kalimat (1) merupakan hiponimi dari (2) pakai masker, saat bertemu orang berjarak secara fisik, cuci tangan, mengurangi pertemuan langsung.

3. Kolokasi ( sanding kata )

Kolokasi ( sanding kata) merupakan asosiasi tertentu dalam diksi. Kolokasi ini dapat berupa antonim atau lawan kata.

Kolokasi atau sanding kata dapat di lihat dari data berikut ini.

1) Sebelumnya, Presiden Joko Widodo atau Jokowi meminta para kepala daerah menerapkan tatanan kehidupan baru atau new normal melalui tahapan yang ketat. Dia mengingatkan anggota dewan atau jajarannya agar betul-betul berhati-hati sebelum menetapkan new normal di suatu daerah. 
2) Gubernur DKI Jakarta menerapkan kehidupan baru di era new normal. Beliau menghimbau agar semua masyarakat tetap memenuhi protokol kesehatan di era new normal tersebut.

3) Presiden Jokowi Dodo adalah antonin dari anggota dewan dan (2) Gubernur adalah antonim dari masyarakat.

Berdasarkan hasil analisis data dan pembahasan yang telah peneliti lakukan, peneliti membuat kesimpulan sebagai berikut.

1. Pertama, penanda kohesi gramatikal dalam berita Covid-19 di Liputan6.com edisi bulan juni 2020 menggunakan penanda reference (pengacuan), substitution (penggantian), penanda ellipsis (pelepasan), penanda konjungsi (kata sambung yang di dalamnya ada penanda konjungsi koordinatif, korelatif, subordinatif, penanda konjungsi antar kalimat.

2. Penanda kohesi leksikal dalam berita Covid-19 di Liputan6.com edisi bulan juni 2020 menggunakan penanda kohesi antonim (lawan kata), penanda kohesi hiponim (hubungan kata atau isi), penanda kohesi kolokasi (sanding kata).

Penanda koherensi dalam berita Covid-19 di Liputan6.com edisi bulan juni 2020 menggunakan penanda koherensi kausalitas, penanda koherensi kontras, penanda koherensi aditif, dan penanda koherensi kronologis.

\section{Kesimpulan}

1. Pertama, penanda kohesi gramatikal dalam berita Covid-19 di Liputan6.com edisi bulan juni 2020 menggunakan penanda reference (pengacuan), substitution (penggantian), penanda ellipsis (pelepasan), penanda konjungsi (kata sambung0 yang di dalamnya ada penanda konjungsi koordinatif, korelatif, subordinatif, penanda konjungsi antar kalimat.

2. Penanda kohesi leksikal dalam berita Covid-19 di Liputan6.com edisi bulan juni 2020 menggunakan penanda kohesi antonim (lawan kata), penanda kohesi hiponim (hubungan kata atau isi), penanda kohesi kolokasi (sanding kata).

3. Penanda koherensi dalam berita Covid-19 di Liputan6.com edisi bulan juni 2020 menggunakan penanda koherensi kausalitas, penanda koherensi kontras, penanda koherensi aditif, dan penanda koherensi kronologis.

Berdasarkan hasil analisis data dan pembahasannya, peneliti memberikan beberapa saran. Untuk peneliti selanjutnya diharapkan lebih baik lagi dan lebih teliti dalam melakukan penelitian dan menganalisis penanda kekohesian dan kekoherensian. Pada penelitian ini, peneliti hanya menjangkau berita pada Liputan6.com dalam media online, hendaknya peneliti lain yang akan meneliti penanda kekohesian dan kekoherensian diharapkan dapat menjangkau 
pada lingkup lain, seperti berita kriminal, berita politik, maupun berita-berita lainnya yang terdapat dalam media online. Penelitian ini hendaknya ditindak lanjuti dari segi penelitian lainnya. Penelitian ini diharapkan dapat dijadikan bahan dan referensi bagi peneliti lain.

\section{E. Daftar Rujukan}

Baryadi, Praptomo.2002.Dasar-Dasar Analisis Wacana Dalam Ilmu Bahasa. Yogyakarta: Pustaka Gondho suli.

Eko Rusminto, Nurlaksana. 2015. Analisis Wacana Kajian Teoritis dan Praktis. Yogyakarta: Graha Ilmu.

Hartanti, Yuanita. 2007. Kohesi dan Koherensi dalam Wacana pada Buku Teks Bahasa dan Sastra Indonesia untuk SMA Kelas X Karangan Dawud, dkk. Terbitan Erlangga. Skripsi SI. Yogyakarta: Program Studi Bahasa dan Sastra Indonesia, FBS Universitas Negeri Yogyakarta.

https://www.liputan6.com/health/read/4268028/update-1-juni-2020-pasien-positif-covid-19bertambah-467-total-26940-orang

https://www.liputan6.com/health/read/4268872/update-2-juni-2020-kasus-positif-covid-1927549-sembuh-7935-meninggal-1663

https://surabaya.liputan6.com/read/4270176/update-corona-covid-19-di-jatim-3-juni-2020pasien-sembuh-bertambah-292-orang

https://www.liputan6.com/bisnis/read/4265826/pns-mulai-jalani-new-normal-5-juni-2020

Kusumawati, Dania. 2018. Jenis Penanda Kekohesian dan Kekoherensian Karangan Deskripsi Siswa Kelas X SMK Negeri 6 Yogyakarta Tahun Ajaran 2017/2018. Skripsi. Yogyakarta: Universitas Sanata Dharma.

Moleong, Lexy J. 2007. Metodologi Penelitian Kualitatif. Bandung: Remaja Rosdakarya.

Mulyana. 2005. Kajian Wacana, Teori Metode dan Aplikasi Prinsip-Prinsip Analisis Wacana. Yogyakarta: Tiara Wacana.

Sugeng Subagyo, Bangkit. 2012. Analisis Kohesi dan Koherensi Rubrik Tajuk Rencana pada Surat Kabar Solopos dan Relevansinya Sebagai Bahan Ajar Pembelajaran Bahasa Indonesia di SMA. Skripsi. Surakarta: Universitas Sebelas Maret.

Widiatmoko, Wisnu. 2015. Analisis Kohesi dan Koherensi Wacana Berita Rubrik Nasional di Majalah Online Detik. Skripsi. Semarang: Universitas Negeri Semarang. 